\title{
Discriminant Analysis of E-Marketing Mix in Online Purchasing Decision and its Implication for Millenials Students Education
}

\author{
Metta Padmalia \\ Program Studi Manajemen, Fakultas Manajemen dan Bisnis, Universitas Ciputra, Indonesia \\ metta.padmalia@ciputra.ac.id
}

\begin{abstract}
The study aims to analyze the variables of e-marketing mix (product, price, place, promotion, personalization, privacy, customer service, community, site, and sales promotion) that can differentiate consumer purchasing decisions from generation millenial and non-millenial. This study is expected to provide an understanding of digital consumer buying behavior related to the generation of millenials students. The study population are all the people who have made a purchase online, while samples are selected based on purposive random sampling as 200 respondents. The data analysis uses a discriminant analysis IBM SPSS Statistics program 22. The test results prove that the discriminant variable sites and communities are able to discriminate against cross-generational purchase decisions.
\end{abstract}

Keywords: Discriminant Analysis, E-marketing Mix, Millenial Generation, Online Purchasing Decisions

\section{INTRODUCTION}

In 2020 the millenial generation is estimated to be the largest in Indonesia. Millenial generation or digital native generation is the generation that grew up in an all-digital environment. Furthermore, according to Fajrian (http://soclab.col mengenal-para-millennial-konsumen-anda/), millennials are optimistic, goal oriented, independent, hopeful, obsessed by success, confident, concerned with lifestyle, and depending on the technology. The survey shows that as many as $58 \%$ of the millennial like shopping, 65\% like culinary and 20\% like traveling. Digital natively supported by a number of technologies to facilitate living, including when deciding on the purchase of the product.

In the digital era, Kalyanam and McIntyre (2002) identified 11 functions of emarketing are described in terms of marketing mix elements (e-marketing mix).
Eleventh functions of e-marketing are product, price, place, promotion, personalization, privacy, customer service, community, site, and sales promotion. The majority of internet users in Indonesia and abroad have made a purchase online. Online shopping start to become a trend because online shopping decision process is not as complicated as offline purchase decision. Shopping online does make it easier, save time and costs compared to traditional shopping.

Two out of ten millennials claim to shop online more than 3 times a month which makes them potential to become "online shopping addicts", most of them are persuaded by discounts or pop-up advertisements made by online shopping websites (Gilang, 2018). Furthermore, Gilang (2018) states that the psychological condition of online shopping addicts has similarities with other addicts. They have both physical 
and psychological dependence on online shopping activities. This is one of the dangers of online shopping for millenials that need to be prevented through the role of education. Santrock (2004: 120) argues that the character education in the form of a direct approach to moral education by giving lessons to students about moral knowledge base to prevent them from immoral behavior or dangerous, both for themselves and for others. In the context of the digital age, character education becomes very important. This is because the Internet is a "wild jungle", in which the contents of positive and negative information mixed together. Only a strong moral foundation within the millennial generation consumers who can ensure the future remains bright Indonesia's young generation, to distinguish the good from the bad. Education in the field of marketing for the generation of millenials should provide insight into Internet usage wisely as to research the digital market, choosing content appropriate to the age and development of target consumers, as well as establishing a good relationship between consumers and businesses in the portal appropriate digital (Benbunan-Fich et al., 2001).

By understanding how consumers use, to process the information they get, then marketers can develop more effective marketing communications. How consumers see the world and learn it, behave and respond to stimuli is the basis for promotional activity. Along the shifting flow of learning psychology of the original wing into perspective cognitive behaviorist orientation, then took shifts are also studies on consumer behavior (Schiffman et al., 2011). A shift in consumer behavior studies of the original using the theory of reinforcement theory into cognitive theory. Cognitive theory study focused on three basic things: information processing, problem solving, and reasoning. Individuals using the information they can from the "external" such as advertising, and from "internal" as a memory. Such information is received, processed, and transferred into the meanings or patterns which are then compiled by the views of consumers about the behavior. Crittenden et al. (2018) argue that cognitive learning is the process of discovering, assimilate new knowledge with the old belief. The orientation Cognitive consumers regard as a problem solver adaptive who use an assortment rationalization process, form concepts, and make it as knowledge. In the cognitive perspective, consumers behave to resolve the problem through a continuous learning process. Emergence of needs and desires, is seen as a problem to be solved. The behavior shown is a problem-solving process.

Purchasing decisions by consumers is a decisive reaction to the company (Rinandiyana et al., 2017). Knowing the factors that influence the consumer's decision is needed by the company to maintain its existence. The process of customers' purchases can be done by looking on various factors.

In the process of purchasing online, one factor is on the translation of marketing mix factors electronically (e-marketing mix) is a factor product, price, place, promotion, personalization, privacy, customer service, community, site, security, and sales promotion (Setiyaningrum et al., 2015). Marketing mix theory shows that several factors in the marketing mix to form a consumer purchasing decisions. Therefore, this study aimed to analyze the variables emarketing mix that can differentiate consumer purchasing decisions from generation millenial and non-millenial, as well as to analyze the variable e-marketing mix is most dominant can discriminate purchasing decisions generation millenial with non-millenial. Respondents millenials generation derived from Ciputra University students to understand the consumer behavior of students at the university.

The revolution in information and communication technologies change the way companies do business and today more and more number of companies that use the Internet and electronic media to conduct the business of marketing. Utilization of the Internet and electronic media to help 
companies conduct marketing activities leads to what is called electronic marketing (emarketing). E-marketing is growing very dramatic and dynamic as the development of information technology and communications from time to time (Setiyaningrum et al., 2015: 371-372).

E-marketing is the marketing done by the company using the Internet and other electronic media, often phones. Specifically, marketing activities through the internet known as online marketing or internet marketing, whereas marketing is done through mobile phones is known for marketing. According to Setiyaningrum et al. (2015: 372), the purpose of e-marketing is to increase marketing efficiency and marketing effectiveness. Although e-marketing can be implemented by all companies regardless of industry type and size of the company, but according to El-Gohary (2010), more common in small businesses. Small businesses are ubiquitous joining an emarketplace, for example Tokopedia, Shoppee, Lazada, OLX, and so on.

E-marketing seen as a new philosophy and modern business practices related to goods, services, information and ideas through the Internet and other electronic means (El-Gohary, 2010). Emarketing definitions vary, for example, Smith and Chaffey (2005) defines emarketing as the achievement of marketing objectives through the application of digital technology. While Strauss and Frost (2001) defines it as the use of electronic data and applications to plan and execute the concept, distribution, and pricing of products to create exchanges that satisfy individual, organization, and purpose. Kalyanam and McIntyre (2002) also defines e-marketing as relational exchanges that occur in the digital environment, network, and interactive.

Kalyanam and McIntyre (2002) identified 11 functions of e-marketing are described in terms of marketing mix elements (e-marketing mix). Here is the eleventh mix of electronic marketing (emarketing mix) proposed Kalyanam and McIntyre (2002).

\section{a. Product (product)}

Product configuration functions map the elements of the marketing mix. However, in the context of e-marketing, product configuration concept can be very complex due to the mechanism of the machine configuration. A company offers configuration engine on his website, which allows customers to design their own product to be bought by a certain configuration (via customization). Today many website companies offer a variety of product features such as information services locally according to the map, services financial information, news services, and so forth that are beneficial to users because it can be accessed whenever and wherever the user is located at a low cost (Kalyanam \& McIntyre, 2002 ; Setiyaningrum et al., 2015).

b. Price (price)

Prices are umym describe what consumers sacrificed to obtain a product or continue a relationship with the company. The sacrifice of not only the sacrifice of money that are financial, but also nonfinancial: the time, effort, licensing, and so on. E-marketing environment allows the use of pricing mechanisms such as dynamic pricing, forward auction, reverse auction, or name your price (Kalyanam \& McIntyre, 2002; Setiyaningrum et al., 2015).

c. Place (place)

Place in the context of e-marketing related to the facilities and location of the transaction. Facilities may occur on the website of the manufacturer of the product. This condition creates the disintermediation because companies can directly sell their products to the final consumer without intermediaries (Kalyanam \& McIntyre, 2002; Setiyaningrum et al., 2015).

d. Promotion (promotion)

Online advertising such as banner ads or pop ups ads, search engines, outbound email and viral marketing are some examples of tools and techniques in the context of the promotion of e-marketing 
(Kalyanam \& McIntyre,
Setiyaningrum et al., 2015).

e. Sales promotion (sales promotion)

Examples of sales promotion activities online is an electronic coupon (e-coupon) are applied in certain times (Kalyanam \& McIntyre, 2002).

f. Site (site)

Website is one of the sites. Digital access point in the form of such sites can be used to interact and customers can obtain information about products and prices, access the latest sales promotions or ask customer service. These access points moderates all functions of e-marketing, so the sites are grouped into the actual function overlapping with another mix function (Kalyanam \& McIntyre, 2002; Setiyaningrum et al., 2015).

g. Personalization (personalization)

Personalization is a form of customization that occurs due to the introduction of certain existing customers. In the context of e-marketing, marketers can use a cookie that is placed on the visitor's computer (Kalyanam \& McIntyre, 2002).

h. Privacy (privacy)

The collection of customer information for purposes persoanalisasi encourage marketers to determine how the information is used, particularly with regard to the determination of who may access such information. Considerations regarding privacy have legal force, thereby increasing the complexity in managing aspects of privacy in the electronic marketing mix (Kalyanam \& McIntyre, 2002; Setiyaningrum et al., 2015).

i. Safety (security)

Functions of e-marketing Equally important is the issue of security, including security-related transaction product purchase using a credit card and security issues related to data recorded from someone who has made a transaction, this data will very likely be exploited by hackers (Kalyanam \& McIntyre, 2002; Setiyaningrum et al., 2015). j. Customer Service (customer service)

The customer service was required for interaction directly and constantly with the customer requires as a customer support functions to be available. Customer service can cover all aspects of e-marketing mix as it pertains to the issue of availability of products, service plans, pricing, or promotion; so that this customer service function into overlapping (Kalyanam \& McIntyre, 2002; Setiyaningrum et al., 2015).

k. Community (community)

Community is a series of the relationship for their mutual interest that satisfy the needs of members, where those needs can not be achieved if done alone. Interaction built to be the exchange of information about the product or provide facilities to frequently asked questions (FAQs). Community development is important in moderating the other marketing functions (Kalyanam \& McIntyre, 2002; Setiyaningrum et al., 2015).

\section{Hypotheses}

Previous research conducted by Sudaryanto and Setiawan (2012) shows that one of the factors that determines purchasing decisions can be analyzed from the marketing mix. D'Esopo \& Almquist (2007) has also previously examined purchasing decisions based on the marketing mix, with the result that the marketing mix designed by the company can be used to shape purchasing decisions offered by the company. This study aims to analyze the e-marketing mix variable that can differentiate consumer decisions in generation $\mathrm{X}$ and $\mathrm{Y}$. The hypotheses in this study are:

$\mathrm{H}_{1}$ : product discriminates against buying decisions in millennial and non millennial generations

$\mathrm{H}_{2}$ : price discriminates buying decisions on millennial and non millennial generations

$\mathrm{H}_{3}$ : place discriminates against purchasing decisions in millennial and nonmillennial generations 
$\mathrm{H}_{4}$ : promotion discriminates against purchasing decisions in millennial and non-millennial generations

$\mathrm{H}_{5}$ : personalization discriminates against purchasing decisions in millennial and non millennial generations

$\mathrm{H}_{6}$ : privacy discriminates against buying decisions in millennial and nonmillennial generations

$\mathrm{H}_{7}$ : customer service discriminates against purchasing decisions in millennials and non millennials

$\mathrm{H}_{8}$ : the community discriminates buying decisions for millennial and nonmillennial generations

$\mathrm{H}_{9}$ : site discriminates against buying decisions on millennial and non millennial generations

$\mathrm{H}_{10}$ : security discriminates against buying decisions in millennial and nonmillennial generations

$\mathrm{H}_{11}$ : sales promotion discriminates against purchasing decisions in millennial and non-millennial generations

\section{METHOD}

In order to this research focuses on the research objectives, the scope of the study was limited to student in Ciputra University Surabaya ever make a purchase online. The primary data is obtained directly from respondents. The method used for data collection technique is by using the tools of the list of questions (questionnaire). This study used an exploratory research that aims to understand a phenomenon or event that emarketing mix influence on purchase decisions online in the generation of nonmillenials millenials and using the assessment of the symptoms or events. The population in this study is an entire generation of millenials and non-millenials who made a purchase online in the emarketplace (Tokopedia, bukalapak, Shoppee, etc.). This study uses a random sampling purposive sampling method with the following criteria: 1) Communities that are located in the city of Surabaya; 2) People who ever make purchases online for himself at least once. This is because in order to understand the object of the research community; 3) Communities that have aged more than 17 years. Age over 17 years are considered capable of taking decisions wisely; 4) Research conducted using discriminant analysis with two categories (millenials and non millenials). In order to sample more homogeneous, then for nonmillenials generation is limited to the generation X who was born in 1961 to 1981 . As for milleials generation or generation $\mathrm{Y}$ are those born in 1981-1995 (Bolton et al., 2013).

Because the population is not known the exact number then use the sample using the method of calculation Hair et al. (2014: 100 ) in which the minimum sample size is as much as 5 times the number of indicators used in research instruments $(5 \times 35=175$ respondents). This research will be distributed questionnaires to 200 respondents who have exceeded the minumum requirements.

In this study, the variables used are divided into two kinds of response variable (dependent) and the independent variable (independent). The response variable in this study is the purchase decision (Y), which are grouped into two general categories: 1) the decision to purchase online millenials generation (Generation Y), and 2) online purchase decision for non millenials generation (Generation X). The independent variable in this study is the Product (X1), Price (X2), Place (X3), Promotion (X4), Personalization (X5), Privacy (X6), Customer Service (X7), Community (X8), Site (X9), Security (X10), and Sales Promotion (X11). In this study are the following operational definitions are adopted from Setiyaningrum et al. (2015) and Meng \& Chatwin (2012): 1) Products: assortment, engine configuration, planning and layout tools; 2) Price: dynamic pricing, forward auction, reverse auction, and name your price; 3) Place: affiliates and remote hosting; 4) Promotion: online ads, sponsored links, outbound e-mail, viral marketing, and recommendation; 5) Personalization: customization and individualization; 6) 
Privacy: rules-based system and collaborative filtering, 7) Customer service: FAQ's and help desk, e-mail response management; 8) Community: chat; 9) Site: home page, navigation and search; 10) Security: secure system; 11) Sales promotion: E-coupon

The analytical method used is the discriminant analysis. The major use of discriminant analysis is twofold. The first is the ability to predict the dependent variable with the independent variable input. The second is the ability to choose which of the independent variables that significantly affect the dependent variable and which are not (Santoso, 2010: 155). Discriminant analysis model is an equation that shows a linear combination of a variety of independent variables, namely:

$\mathrm{D}=\mathrm{b}_{0}+\mathrm{b}_{1} \mathrm{X}_{1}+\mathrm{b}_{2} \mathrm{X}_{2}+\mathrm{b}_{3} \mathrm{X}_{3}+\mathrm{b}_{4} \mathrm{X}_{4}+\mathrm{b}_{5} \mathrm{X}_{5}+$ $\mathrm{b}_{6} \mathrm{X}_{6}+\mathrm{b}_{7} \mathrm{X}_{7}+\mathrm{b}_{8} \mathrm{X}_{8}+\mathrm{b}_{9} \mathrm{X}_{9}+\mathrm{b}_{10} \mathrm{X}_{10}+\mathrm{b}_{11} \mathrm{X}_{11}$, where :

D : Discriminant scores

b : Discriminant coefficients

$\mathrm{X}_{1}-\mathrm{X}_{11}$ : Independent variable

In accordance with the characteristics of the discriminant analysis, the independent variables, namely e-marketing mix at least scale interval measurement, while the dependent variable measurement scale categorically nominal and measured (make a purchase decision and decide not to buy). To make categorical following steps: 1) summing the total score of each respondent, 2) summing the total score of all respondents,

3) average the total score of all respondents,

4) classifying the total score of each respondent based on the average score of the total all respondents, the respondents with a total score equal to or above the average total score of all respondents were classified as respondents who decide a purchase, whereas respondents with a total score below the average total score of all respondents were classified as respondents who decided not to buy. Data analysis procedure performed by IBM SPSS Statistics 22.

\section{RESULT AND DISCUSSION}

Respondent characteristics were analyzed in order to determine the demographic characteristics of the respondents. Here is the explanation:

Table 1. Respondents Data

\begin{tabular}{llllll}
\hline \multirow{2}{*}{ Gen } & \multicolumn{2}{c}{ Gender } & \multicolumn{3}{c}{ Last Education } \\
\cline { 2 - 6 } & Man & Woman & High school & Bachelor & Post-graduate \\
\hline $\begin{array}{l}\text { Millenials } \\
\text { (Gen Y) }\end{array}$ & 65 people & 73 people & 118 people & 14 people & 6 people \\
Percentage & $47.1 \%$ & $52.9 \%$ & $85.5 \%$ & $10.1 \%$ & $4.4 \%$ \\
Non- & & & & & \\
millenials & 42 people & 20 people & 33 people & 14 people & 15 people \\
(Gen X) & & & & & \\
Percentage & $67.7 \%$ & $32.3 \%$ & $53,20 \%$ & $22.6 \%$ & $24.2 \%$ \\
\hline
\end{tabular}

Source: Processed Primary Data

Based on Table 1, it can be seen that the respondents from the millennials generation with female gender $(52.9 \%)$ are more than men $(47.1 \%)$. Last education respondents are high school-equivalent $(85.5 \%)$, bachelor $(10.1 \%)$, and masters (4.4\%). Respondents from non-millenials generation of sexed men $(67.7 \%)$ are more than women $(32.3 \%)$. Latest education are high School-equivalent (53.2\%), followed by courses $(24.2 \%)$ and bachelor $(22.6 \%)$.

This research also observe what emarketplace and what kind of product from millenials and non-millenials usually bought online (Table $2 \&$ Table 3 ).

Table 2. Frequently visited e-marketplaces

\begin{tabular}{llllll}
\hline \multicolumn{1}{c}{ Gen } & Toko-pedia & Bukalapak & Shoppe & Lazada & Blibli \\
\hline Millenials & 40 people & 21 people & 55 people & 12 people & 10 people \\
Percentage & $29 \%$ & $15.2 \%$ & $39.9 \%$ & $8.7 \%$ & $7.2 \%$ \\
$\begin{array}{l}\text { Non- } \\
\text { millenials }\end{array}$ & 32 people & 15 people & 8 people & 2 people & 5 people \\
Percentage & $51.6 \%$ & $24.2 \%$ & $12.9 \%$ & $3.2 \%$ & $8.1 \%$
\end{tabular}

Source: Processed Primary Data

Table 3. Kind of product usually bought online

\begin{tabular}{ccclll}
\hline \multicolumn{1}{c}{ Gen } & Fashion & Electronic & Cosmetic & Health-goods & Others \\
\hline Millenials & 67 people & 31 people & 24 people & 13 people & 3 people \\
Percentage & $48.6 \%$ & $22.5 \%$ & $17.4 \%$ & $9.4 \%$ & $2.2 \%$ \\
$\begin{array}{l}\text { Non- } \\
\text { millenials }\end{array}$ & 15 people & 5 people & 12 people & 29 people & 1 people \\
Percentage & $24.2 \%$ & $8.1 \%$ & $19.4 \%$ & $46.8 \%$ & $1.6 \%$ \\
\hline
\end{tabular}

Source: Processed Primary Data 
Based on Table 2, e-marketplace that usually visited by millenials is Shoppe (39.9\%) and by non-millenials is Tokopedia (51.6\%). Then from Table 3, millenials usually buy fashion products $(48.6 \%)$ and non-millenials usually buy health-goods $(46.8 \%)$.

Table 4. Tests of Equality of Group Means

\begin{tabular}{llrllll}
\hline & Wilks' & F & $\mathrm{DF}_{1}$ & $\mathrm{DF}_{2}$ & Sig. \\
\hline Products (X1) & 0,68888889 & 1.539 & 1 & 198 & 0,15 \\
Price (X2) & 0,69375 & 0,17430556 & 1 & 198 & 0,42847222 \\
Place (X3) & 0,69236111 & 0,45069444 & 1 & 198 & 0,29305556 \\
Promotion (X4) & 0,67222222 & 6.599 & 1 & 198 & 0.011 \\
Personalization (X5) & 0,66805556 & 7.906 & 1 & 198 & 0.005 \\
Privacy (X6) & 0,69375 & 0,13402778 & 1 & 198 & 0,45902778 \\
Cust. Service (X7) & 0,67361111 & 6.161 & 1 & 198 & 0.014 \\
Community (X8) & 0,69097222 & 1.091 & 1 & 198 & 0.018 \\
Site (X9) & 0,63611111 & 18.201 & 1 & 198 & 0.000 \\
Security (X10) & 0,68958333 & 1.409 & 1 & 198 & 0,16458333 \\
Sales promotion (X11) & 0,68819444 & 1.733 & 1 & 198 & 0,13194444 \\
\hline Source: Processed Primary & Data & & &
\end{tabular}

Based on Table 4 - Test of Equality of Group Means in this study, only the variable $\mathrm{X} 4 \quad$ (promotion), $\mathrm{X} 5$ (personalization), X7 (customer service), X8 (community), and X9 (sites), which has a sig $<0.05$, then these five variables that make a difference in decision-making (Y).

Table 5. Canonical Discriminant

\begin{tabular}{|c|c|c|c|c|}
\hline Function & Eigenvalue & $\begin{array}{c}\% \\
\text { of Variance }\end{array}$ & $\begin{array}{c}\text { Cumulative } \\
\%\end{array}$ & $\begin{array}{l}\text { Canonical } \\
\text { Correlation }\end{array}$ \\
\hline 1 & $26.229^{\mathrm{a}}$ & 100.00 .00 & 100.00 .00 & 0,5625 \\
\hline
\end{tabular}

From Table 5, the value of canonical correlation of 0.810 when squared is 0.6561 means that $65.61 \%$ of variance of the independent variable. Value canonical correlation shows the relationship between the value of the discriminant with a group with a value of 0.810 means that do have a high cohesion because it is more close to 1 (the magnitude of the correlation between 0 $1)$.

Table 6. Wilk's Lambda Chi-Square

Test of Function (s) Wilks' Lambda Chi-square df Sig.

\begin{tabular}{lllll}
\hline 1 & 0,61875 & 22.637 & 2 & 0.000 \\
\hline
\end{tabular}

Source: Processed Primary Data
Table 6 illustrates that the significant value of chi-square statistic is $0.000(<0.05)$ means that there is a significant difference between the two groups of respondents based on two independent variables.

Table 7. Standardized Canonical Discriminant Function Coefficients

\begin{tabular}{ll}
\hline & \multicolumn{1}{c}{ Function } \\
\cline { 2 - 2 } Site & 1 \\
Community & 1.024 \\
Source: Processed Primary Data, & -0.519 \\
& \\
Table 8. Structure Matrix & \\
\hline & Function \\
\cline { 2 - 2 } & 1 \\
\hline Site & 0,60347222 \\
Customer Service & 0,27430556 \\
\hline Personalization & 0,175 \\
Community & -0.213 \\
Promotion & 0,12083333 \\
Security & 0,156 \\
Place & 0,07638889 \\
Sales Promotion & 0,053 \\
Privace & -0.035 \\
Product & 0.027 \\
\hline Price & 0.008 \\
\hline Source: Processed Primary Data & \\
& \\
\hline & \\
\hline
\end{tabular}

Table 7 and 8 explain the sequence of the most distinguishing characteristics of a decision (Y). Variable X9 (the site) is the most distinguishing variable, then the variable $\mathrm{X} 8$ (community). Other variables can not distinguish a purchase decision. Based on Table 9 explains that the correlation between independent variables with discriminant function is formed. Variable X9 (the site) is variable with the highest correlation with the correlation of 0.869 .

Table 9. Canonical Discriminant Function Coefficients

\begin{tabular}{lc}
\hline & Function \\
\cline { 2 - 2 } Site (X9) & 1 \\
Community (X8) & 0.472 \\
(Constant) & -0.267 \\
unstandardized coefficients & -1.774 \\
\hline \multicolumn{2}{l}{ Source: Processed Primary Data }
\end{tabular}


Table 9 describes the discriminant function with the following equation: $\mathrm{Z}$ score $=-1.774$ (constant) $-0.267+0.472 \times 8 \times 9$. This function is useful to analyze the respondents surveyed would be included in the generation of non-millenials (decision 0 ) or the generation of millenials (decision 1).

Table 10. Functions at Group centroids

\begin{tabular}{lr}
\hline \multirow{2}{*}{ Generation } & \multicolumn{1}{c}{ Function } \\
\cline { 2 - 2 } & \multicolumn{1}{c}{1} \\
\hline Generation X & -0.473 \\
Generation Y & 0,177083333 \\
\hline
\end{tabular}

Source: Processed Primary Data

Discriminant function equation is: Value $\mathrm{Z}=-1.774$ (constant) -0.267 (X8) + 0.472 (X9)

Table 11. Classification Function Coefficients

\begin{tabular}{lll}
\hline & \multicolumn{2}{c}{ Generation } \\
\cline { 2 - 3 } & Gen X & Gen Y \\
\hline Site (X9) & 1.339 & 1,683 \\
Community (X8) & 2.961 & 2,767 \\
(Constant) & -26.497 & -27.708 \\
\hline
\end{tabular}

Source: Processed Primary Data

Table 11 illustrates that there is the same thing as part of Canonical Discriminant Function Coefficients previously discussed. The equation is as follows:

For Generation $\mathrm{X}$ (non-millenials), the equation:

Value $=-26.497($ constant $)+2.961(X 8)+1.339(X 9)$

For Generation Y (millenials), the equation: Value $=-27.708($ constant $)+2.767(X 8)+1.683(X 9)$

Based on the Test of Equality of Group Means that can be seen in Table 4, it is known that the $\mathrm{X} 4$ (promotion), $\mathrm{X} 5$ (personalization), $\mathrm{X} 7$ (customer service), $\mathrm{X} 8$ (community), and $\mathrm{X} 9$ (sites) influential in providing the difference in decision-making ( Y) due to the significant value of the four variables $<0.05$. As for the other variables significance value $>0.05$, which means that other variables can not make a difference in decision-making $(\mathrm{Y})$. Under these conditions, only $\mathrm{H} 4, \mathrm{H} 5, \mathrm{H} 7, \mathrm{H} 8, \mathrm{H} 9$ which proved significant and can discriminate purchase decisions on the Millennials generation and non-millenials. For H1, H2, H3, H6, H10, and $\mathrm{H} 11$ can not be proved significantly.

Discriminant analysis test does not just stop at testing the hypothesis only, but followed by other testing. According to the table structure matrix, it is known that the only variable X8 (community) and X9 (sites) that have the characteristics to distinguish intergenerational purchasing decisions, while others do not. Furthermore, the preparation of the discriminant function to analyze the respondents surveyed belong to the first group or the second, in the study of nonmillenials generation and the generation of Millennials. The resulting discriminant function is:

$\mathrm{Z}$ score $=-1.774$ (constant) $-0.267(\mathrm{X} 8)+0.472$ (X9)

In addition to the discriminant function equation, the equation is also prepared for each group as follows:

Generation of non-millenials:

Value $=-26.497($ constant $)+2.961(X 8)+1.339(X 9)$

Generation millenials:

Value $=-27.708($ constant $)+2.767(X 8)+1.683(X 9)$

This research has been done to understand the factors of e-marketing mix that is able to discriminate purchase decisions on millenials generation and nonMillennials. Respondents came from Surabaya people who is taken at random sampling, who is ever conduct online transactions on e-marketplace or in other words, do online shopping. Online shopping by Mujiyana and Ellisa (2013) is the process whereby consumers directly buy a product from a seller interactively and in real-time without media intermediaries and done over the internet. Shopping via the Internet allows a prospective buyer can see the first products to be purchased through the website promoted by the seller, or through the emarketplace that accommodate many sellers 
to enable it to transact online. Online shopping activity is a form of communication that does not require direct face to face, so that it can be done separately from anywhere via the Internet.

In this study, used aspects of emarketing mix (Setiyaningrum et al, 2015) as a variable to discriminate purchasing decisions intergenerational on online purchases of product, price, place, promotion, personalization, privacy, customer service, community, site, security, and sales promotion. The test results prove that the only variable discriminant communities and sites that are able to discriminate against an online purchase decision on millenials generation and the generation of non-millenials. Although the tables Test of Equality of Group Means indicates that the variable promotional, personalized, customer service, community, and the site can make a difference in decision-making but it was variable promotions, personalization, and customer service is not strong purchasing decisions discriminate between generations.

Prandelli and Verona (2006) proposed a model $3 \mathrm{Cs}$ of marketing mix in the digital age, for which every $\mathrm{C}$ contains several key elements: content (site), community (platform interaction and the ability relational), commerce (including 4P: product, price, place and promotion). Based on the model proposed by Prandelli and Verona, it can be seen that the site and the community is a new thing that distinguishes the traditional with the digital marketing mix. Therefore, the e-marketing mix was only sites and communities proved able to discriminate between generations purchasing decisions online. Allegedly digital marketing mix that others can not discriminate between generations purchasing decisions for both the generation of non-millenials and millenials are accustomed circuitry other tools such as not much different from the traditional marketing mix which is more commonly known.

Differences birth year will form a different generation, in this study were separated as non-millenials generation/ generation $X$ (1961-1981) and millenials generation/ Generation Y (1981-1995) in accordance with the proposed division of Bolton et al. (2013). Differences year of birth is one of the causes of intergenerational have different attitudes to information, because every generation living in the era of a different era, including the development of information technology. Judge (2010) says that every generation has a culture, the level of utilization of different technologies and different lifestyles.

One of the e-marketing tools according to the proposed model Kalyanam and McIntyre (2002) is a site, which is a digital container that is used to interact with customers. Based on the test results of the discriminant, the site is able to discriminate online purchase decisions among different generations. The important role of the site in digital marketing among others represent the company's presence on the internet virtually, as a means of offering products and communicate with consumers, as media companies in maintaining customer loyalty, as a means to reach consumers more broadly is not limited to the distance, as well as a means of purchase products offered (Sarwono and Prihartono, 2012). Hence the importance of the site in the development of online business, the role of this site should be more tailored to the needs of different customers each generation because test results showed the presence of variable statistics can discriminate sites online purchase decisions of two different generations.

Other e-marketing tools according to the proposed model Kalyanam and McIntyre (2002), which proved to discriminate against an online purchase decision is a community; represented by attributes chat rooms, user ratings and reviews, registries and wish lists, as well as the reputation scoring (Setiyaningrum et al., 2015). Companies can interact with its customers through a community that was built as one of the emarketing mix by commenting on websites, blogs, social networking and even 
deliberately (Ward, 2015). Chaffey and EllisChadwick (2016) explains that marketers should be able to create and manage a social community environment as one of the competitive advantages of companies in the digital era.

Furthermore, it is explained that one of the interactions that are built in the community is to provide an opportunity for consumers to provide comments are then addressed the company, give ratings on the company, as well as share their experiences with the brand among members of the online community (Chaffey and Ellis-Chadwick, 2016). Interactions were allegedly meant more common in millenials generation, based on the exposure of Quester et al. (2007) which states that the characteristics of millenials generation is like expressing yourself emotionally and share their experiences with others than the generations that came before. It supports discrimination test results on consumer online purchases in Surabaya that community that was formed in digital marketing can distinguish purchase decisions on millenials generation with nonmillenials. Therefore, the existence of online communities should be managed in a better targeted to reach consumers from different generations.

Furthermore, the two independent variables (sites and communities) are able to explain the variations in purchase decisions online by $65.61 \%$. It shows that at least more than half of online purchasing decisions intergenerational variation able to be explained by the independent variables. From these two independent variables, the site of a dominant variable in discriminating purchasing decisions online. The dominance of the site variables can be explained that in deciding to buy a product online, the consumer generation to generation millenials non-millenials there is a difference. The difference among others influenced by the definition of a clear product features, setting display e-marketplace sites, as well as tools that allows consumers to find items and products more easily. Allegedly on nonmillenials generation which, according to
Wuest et al. (2008) were more likely to make a purchase to the brand that has a good quality according to their criteria, so as not to pay attention to the look and ease of access to e-marketplace when making purchases online.

Muslich (2011: 17) said that the current education for millenials students tend to provide a portion of the many aspects of knowledge, making it less able to develop values, attitudes, and character. Though Santrock (2004: 120) has clearly stated that the character education for the younger generation is important to distinguish between what is good and what is bad. In the digital era that completely ease the flow of this information to be as good an education in marketing provides a good charge associated with creating the right content to fit the company's website for the promotion that will ultimately influence purchase decisions online according to the target market, especially for millenials students. Van Doren and Corrigan (2008) proposed the existence of direct learning with the business community can influence the understanding of the concept of corporate marketing. It is one that will eventually also affect consumer behavior in the generation of millenials in the digital era.

The role of higher education in the field of marketing by Harrigan and Hulbert (2011) is to reflect the nature of disruptive technologies and expanding into marketing practices, as well as to prepare the student to put in place the appropriate marketing concepts. Furthermore, Harrigan and Hulbert (2011) also created the concept of "the new marketing DNA" containing marketing concepts that need to be given to education marketing in the digital era. Aspects of the " the new marketing DNA " includes the customer-led marketing that puts the customer insight in developing marketing strategies, value-driven strategic marketing, channels, data-driven marketing and marketing communications online and offline. These concepts should be given to the education of marketing for the current generation so as to improve the marketing 
competence to learners when they do business to improve purchasing decisions.

\section{Conclusion}

This research concluded that e-marketing mix becomes the determining purchase decisions online in a different generation (non-millenials and millenials). The existence of the e-marketing mix that can discriminate between generations of online purchase decisions are based on variable sites and communities by $65.61 \%$. Directions for research that can be done later arise due to the limitations of this study. First, the comparison sample millenials generation with better non-millenials be balanced, in this study tend to be less balanced proportions. Second, the homogeneity of the sample should be considered. Third, the determination of sample criteria narrowed, for example, only to consumers who purchase from a particular e-marketplace, given the variety of attributes offered in each e-marketplace is different. Fourth, further research needs to be done to deepen the factors that shape consumer behavior across generations.

\section{REFERENCES}

Benbunan-Fich, R., Lozada, H. R., Pirog, S., Wisenblit, J., \& Priluck, R. (2001). Integrating Information Technology into the Marketing Curriculum: A Pragmatic Paradigm. Journal of Marketing Education, Vol. 23 No. 1, p. 5-15.

Bolton, RN, Parasuraman, A., Hoefnagels, A., Migchels, N., Kabadayi, S., Gruber, T., Loureiro, YK, and Solnet, D. (2013). Understanding Generation $\mathrm{Y}$ and Their Use of Social Media: a Review and Research Agenda. Journal of Service Management, Vol. 24, No. 3, p.245-267.

Chaffey, D. and Ellis-Chadwick, F. (2016). Digital Marketing: Strategy, Implementation, and Practice. London: Pearson.

Crittenden, W.F., Biel, I.K., and Lovely, W.A. (2018). Embracing
Digitalization: Student Learning and New Technologies. Journal of Marketing Education, Vol. 41, No. 1, pp: 5-14.

D'Esopo, M. \& Almquist, E. (2007). An Approach to MasteringThe Marketing Mix. Business Strategy Series, Vol. 8, No. 2, pp.122-131.

El-Gohary, H. (2010). E-Marketing - A Literature Review from a Small Business Perspective. International Journal of Business and Social Science, Vol 1, No.1.

Gilang, G. (2018). Online shopping can make addiction, this is a psychologist's explanation(https://www.brilio.net/cre ator/-millenials-waspada-kecanduanonline-shopping-121952.html).

Hair, JF, Black, WC, Babin, BJ, and Anderson, RE (2014). Multivariate Data Analysis 7th Edition. USA: Pearson Education Limited.

Harrigan, P., \& Hulbert, B. (2011). How Can

Marketing Academics Serve Marketing Practice? The New Marketing DNA as a Model for Marketing Education. Journal of Marketing Education, Vol. 33, No. 3, pp: 253-272.

Hasan, A. (2008). Marketing. Yogyakarta: Media Pressindo.

Kalyanam, K. \& McIntyre, S. (2002). The EMarketing Mix: A Contribution of the E-Tailing Wars. Journal of the Academy of Marketing Science, Vol. 30, No. 4, pp 483-495.

Kotler, P. (2003). Marketing Management. Elevent Edition. USA: Pearson Education, Inc.

Kotler, P. and Armstrong, G. (2001). Principles of Marketing (Translation). The eighth edition. Jakarta: Erlangga.

Kotler, P. and Keller, KL (2007). Marketing Management. Twelfth Edition. Jakarta: Erlangga.

Meng, SK \& Chatwin, C. (2012). Measuring E-Marketing Mix Elements for Online Business. International Journal of E-Entrepreneurship and Innovation, Vol 3, No. 3. 
Mujiyana \& Elissa, I. (2013). Analysis of Factors Influencing Purchase Decision via the Internet at the Online Store. Journal of Industrial Engineering, September 2013: 143152.

(Https://ejournal.undip.ac.id/index.ph p/jgti/article/view/5382)

Prandelli E., \& Verona G. (2006). Marketing in Rete, Milan: McGraw-Hill.

Quester, P., Neal, C., Pettigrew, S., Grimmer, M., Davis, T. \& Hawkins, D. (2007). Consumer Behavior: Implications for Marketing Strategy, 5th ed. Sydney: McGraw-Hill.

Rinandiyanaa, LR, Kurniawati, A., and Kurniawan, D. (2017). Analysis of Factors Influencing Purchase Decision by the Millennial Generation in the culinary industry in Tasikmalaya. Journal of Economics, Vol 3, No. 1, pp 18-27.

Santrock, J.W. 2004. Educational Psychology 2nd ed. New York: McGraw-Hill Companies, Inc.

Schiffman, LG \& Kanuk, LL (2000). Consumer Behavior. Seventh Edition. USA: Prentice-Hall, Inc.

Schiffman, L.G., Hansen, H. and Kanuk, L. (2011). Consumer Behavior: A European Outlook. New York: Prentice Hall.

Setiyaningrum, A., Udaya, J., and Efendi. (2015). Principles of Marketing. Yogyakarta: Andi.

Smith, PR \& Chaffey, D. (2005). Emarketing Excellence: The Heart of eBusiness. Elsevier Butterworth-Heinemann.

Strauss, J. and Frost, R. (2001). E-Marketing. Second Edition. New Jersey: Prentice-Hall, Inc., Upper Saddle.

Sudaryanto, \& Setiawan, DI (2012). Discriminant Analysis Marketing Mix Buying Decision Against Daily Morning Radar Jember. Journal of Business and Management, VI, 3444.

Ward, A. (2015). Digital Marketing Strategy and Its Implications on SME Competitive Advantage in Indonesia.
Conference Paper Finance and Business Forum IV. ISBN: 978-60217225-4-1.

Wuest, BES, Welkey, Mogab, and Nicols. (2008). Exploring Consumer Shopping Preferences: Three Generations. Family and Consumer Sciences Research Journal, 100 (1): 31-37.

http://soclab.co/mengenal-para-millennial-

konsumen-andal 